$\mathbb{T}$ periodica polytechnica

Social and Management Sciences $17 / 1$ (2009) 41,45

doi: 10.3311/pp.so.2009-1.04 web: http://www.pp.bme.hu/so

(c) Periodica Polytechnica 2009

RESEARCH ARTICLE

\section{Investment optimisation for the reduction of the emissions of settlements}

\author{
Mária Csete / Ádám Török
}

Received 2010-01-05

\begin{abstract}
In the compensation of the effects of global climate change, mitigation is always a key issue. The initiatives towards this goal are usually nationwide, and restricted to large scale facilities, although households, small settlements and subregions also contribute to the reduction of emissions, which - among others - could be realised by investments and developments. The optimisation of the investments aimed toward local environmentaleconomical and climate protection goals could help the decision makers to assemble an environmentally friendly, climate conscious and cost-effective investment portfolio. These local endeavours and solutions fully correspond to the international and domestic climate protection efforts. In this paper, we would like to introduce the dynamic optimisation of environmental investments of local and subregional settlement development. This only differs from the optimisation methods used in economics for investment and production optimisation methods in the boundary conditions applied. We used boundary conditions related to environmental and climate protection and adaptation.
\end{abstract}

\section{Keywords}

climate change $\cdot$ mitigation $\cdot$ local and subregion level investments $\cdot$ optimisation

\section{Mária Csete}

Department of Environmental Economics, BME, 1111 Budapest, Múegyetem rkp. 9., Hungary

e-mail: csete@eik.bme.hu

\section{Ádám Török}

Department of Transport Economics, BME, 1111 Budapest, Múegyetem rkp. 9., Hungary

e-mail: atorok@kgazd.bme.hu

\section{Introduction}

The importance of research into the economic aspects within the system of phenomena and complex procedures connected to climate change is also confirmed by the dangers to the Hungarian national economy resulting from the change in the environment. With the help of our investigations in this study and our model, we specify the costs and benefits of economic and environmental protection investments and establish their optimal launch time and order.

In the National Climate Change Strategy of Hungary, the monetary requirements of preparation, prevention, defence, and restoration, the social sacrifices or the costs and human resource conditions of settlements, enterprises and citizens did not get the emphasis that their importance implies, even though they are cardinal points of the practical implementation of the Strategy. With our model, we would like to approach this topic from the angle of local level investments.

Because of the complexity of the topic, a multi-criteria approach is necessary in the tests to measure the economic relationships and different effects of climate change. An approach with more viewpoints is necessary. Within this complex topic, our study is focusing on mitigation, adaptation and local economic initiatives and investments that are environment-related and improve the quality of life.

One of Hungary's specific features lies in its municipal system; because among the more than 3200 settlements, the proportion of small settlements is outstandingly high. This scattered municipal system, with its broad range of obligations and responsibilities, yet often insufficient funds is unique in Europe.

Law No. LXV of 1990 summarises the obligatory tasks of local governments. Among other things, they must provide the drinking water supply, healthcare and social care, the maintenance of local public transport and public roads, etc. In certain areas, the local government defines the extent of completing the tasks; a decision greatly influenced by not only the needs of the population, but the financial facilities as well.

Compared to the EU average, the higher rate of the rural areas is typical in Hungary, the sensitivity and vulnerability of which - from a given aspect - is higher than that of other well devel- 
oped areas [2].

Dealing with the local level is especially important because of the practices and the current state of local governments. This is true in relation to climate change as well, even though this may seem an impossible additional task. In our study we have chosen the settlement level because it is not hopeless to harmonize different objectives, settlement liveability, the environment, climate protection and adaptation initiatives with a proper methodology that we will describe herein. The importance and urgency of this is underlined by the fourth assessment report of the IPCC [5], because settlements are the stakeholders that are able to represent the wide circle of the local inhabitants while being responsible for providing numerous services [12].

The power consumption of households and smaller settlements with micro-regional aims (Fig. 1) is considerable, has low efficiency, and the saving opportunities are scarce.

Poor thermal insulation on buildings and the lack of attention to local traffic and roads have further negative impacts on the above. A large amount of investment is needed for positive changes, and returns take long to realize. Furthermore, the procreation of private resources to the applications also meets difficulties.

The local climate protection initiatives can only be effective with the simultaneous application of both adaptation and mitigation strategies. The population living in settlements makes use of $40 \%$ of the world's energy, which in turn contributes to the global $\mathrm{CO}_{2}$ emissions by some $31 \%$ (of which $21 \%$ is emitted by the buildings) [6]. Adaptation and atmosphere protection are often strongly interconnected (e.g.: alternative energy sources, green areas, limited soil relocation, etc.). In this case, our investigations focus on mitigation, taking into consideration both finished and ongoing sub-regional or settlement level projects.

It is practical to apply suitable incentives in the interest of the conservation of the local quality of life. The solutions which are cost effective, economical and also protect the environment, and as an additional positive externality contribute to the hygiene (e.g.: by improving air quality) and the living conditions of the local residents improving, and even a job opportunity is created for the local specialists.

According to the Stern Review [9] investments aimed at mitigation are supposed to be considered as disbursed expenses occurring presently or in the next decades, and are helping to lower the risks of the future consequences.

\section{The presentation of the mathematical model}

In this paper, our goal is the economical optimisation of subregional investments, in the interest of the promotion of the practical realisation of endeavours. To achieve this, we made use of the tools of linear programming. We presumed that the material resources of a subregion are scarce, and that the role of environmental protection is becoming an important investment assessment factor. As a first step toward solving this problem, we defined the investments to be realised, whose primary aim is the reduction of the environmental load on subregions. Then, we chose the evaluation criteria, the efficiency criteria and boundary conditions of the investments. The examined problem belongs to the dynamic problem family of models, since the launch time of the investment is the most important factor to the achievement of the objective function and the limiting conditions. Let us suppose, that we have $n$ possible investment variants, and $k$ technical, economic and social features, with which the single investment variants take action in a different degree, furthermore, that the time span of the examination is $t$ year.

As the objective function (1) we defined the cost function of all of the subregional projects, which includes the investment expenses, and the discounted operational costs in the function of the time.

$$
Z=\sum_{t=0}^{m}\left(\sum_{i=1}^{n}\left(k_{i t} \cdot x_{i t}\right)\right)+\sum_{t=0}^{m}\left(\sum_{i=1}^{n}\left(\frac{s_{i t}}{(1+r)^{t}} \cdot x_{i t}\right)\right)
$$

where:

$Z$ : the fulfilment expenses of the subregion projects [HUF]

$k_{i t}$ : the investment expense of the project $\mathrm{i}$ the in the year $\mathrm{t}$ [HUF]

i: $\quad$ the number of carbon neutral projects 1..i...n [-]

$\mathrm{t}$ : the duration of the examination 1..t..m [year]

$x_{i t}$ : the number of projects to be realized in the year $\mathrm{t}$ [pcs]

$s_{i t}$ : the operational costs of the project $\mathrm{i}$ in the year $\mathrm{t}$ [HUF/year]

$r$ : the discount rate counted on the unit of the investment [\%], in our model 5\%1

Our aim is to minimise the objective function beside the satisfaction of the limiting conditions:

$$
x_{i t} \geq 0(i=1,2, \ldots, n) \text { and } \quad(t=0,1, \ldots, m)
$$

So the number of project variants realized in the year $t$ is not negative.

$$
\sum_{t=0}^{m} a_{i j} \cdot x_{i t}=A_{j}(j=1,2, \ldots, k)
$$

where

$a_{i j}$ : coefficient, that is marking the efficiency of the variant $i$ opposite the feature $j$ (for example due to the insulation $600 \mathrm{~kg} \mathrm{CO} 2 \mathrm{e} /$ year/flat emission decrease can be achieved).

$A_{j}$ : the marginal values of the efficiency indicators, which we want to achieve with the realisation of the given investment program (for example: under 20 years we would like to attain $500 \mathrm{t} \mathrm{CO}_{2} \mathrm{e}$ emission decrease)

\footnotetext{
${ }^{1}$ Upon choosing the discount rate, we made use of the available bibliography. For example, according to the research of the UN-UNEP, for the long-term energy forecasts low (3-5\%) discount rate is offered ([11]p.53).
} 

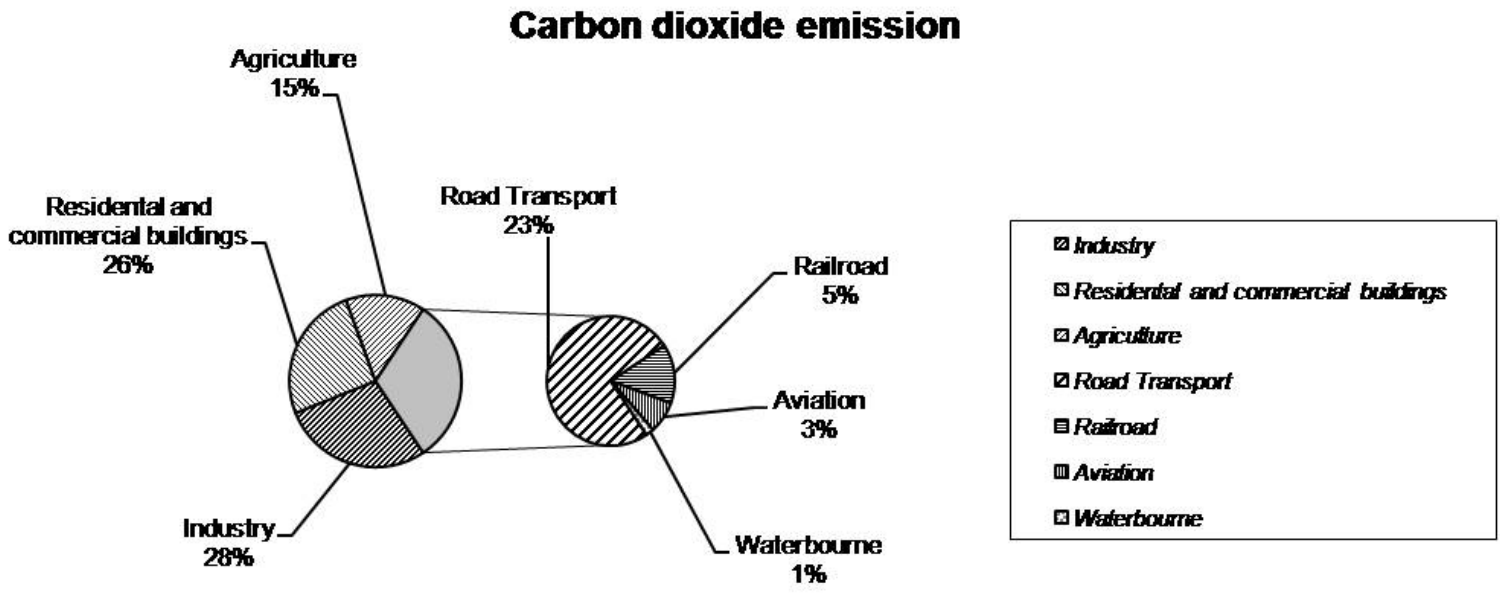

Fig. 1. The distribution of anthropogenic carbon dioxide emission

Tab. 1. The implementation data of the project plan

\begin{tabular}{|c|c|c|c|c|}
\hline & Cost of investment & Cost of upkeep & $\mathrm{CO}_{2}$ reduction & $\begin{array}{l}\text { Timeframe } \\
\text { (year) }\end{array}$ \\
\hline \multirow[t]{2}{*}{ Insulation } & 10000000 & 0 & 600 & 1 \\
\hline & HUF/flat & HUF/flat & $\mathrm{kg} \mathrm{CO}_{2} \mathrm{e} /$ year/flat & \\
\hline Heating modernisation & 400000 & 25000 & 100 & 1 \\
\hline (furnace, etc.) & HUF/flat & HUF/flat & $\mathrm{kg} \mathrm{CO}_{2} \mathrm{e} /$ year/flat & \\
\hline \multirow[t]{3}{*}{ Education } & 0 & 50000 & 50 & 1 \\
\hline & HUF/person & HUF/person & $\mathrm{kg}$ & \\
\hline & & & $\mathrm{CO}_{2} \mathrm{e} /$ year/person & \\
\hline \multirow[t]{2}{*}{ Building of bicycle lanes } & 30000000 & 0 & 130 & 10 \\
\hline & $\mathrm{HUF} / \mathrm{km}$ & $\mathrm{HUF} / \mathrm{km}$ & $\mathrm{kg} \mathrm{CO}$ e/year & \\
\hline
\end{tabular}

Source: (Own research)

\section{The application of our model}

In our paper, we took the fulfilment parameters of the following project plans for a twenty year period as a starting point.

As a boundary condition, we presumed that 2400 people live in the settlement in 600 households. The overall $\mathrm{CO}_{2}$ emission for the community is $19200 \mathrm{t} \mathrm{CO}_{2} \mathrm{e} /$ year (Energy Information Administration International Energy Annua ${ }^{2}$, 2003.) and this should be reduced over 20 years by $500 \mathrm{t} \mathrm{CO}_{2} \mathrm{e}$. The residents would like to be given a climate protection education, also, it would be necessary to modernise the heating in all 600 households, to renovate and insulate the buildings, and the local government would like to have $10-10 \mathrm{~km}$ of bicycle lanes built as a duplicate investment within 20 years at the lowest possible cost, such that annually a maximum of 200 million HUF may be spent on investments of this type.

The summary of the project plan fulfilling the boundary conditions is shown on Fig. 2

From the analysis of the optimal (minimal expense) project portfolio that satisfied boundary conditions, it can be derived that from the viewpoint of cost effectiveness and environmental

\footnotetext{
${ }^{2}$ Source: http://www.eia.doe.gov/
}

protection, heating modernization, education and mind shaping projects have priority in the first year. In the second year the insulation works of the buildings begin, as well as the construction of the bicycle lane, whilst the heating modernisation works are completed. The planned insulation works will be finished in the second, third and the fourth years. The second phase of the building of the bicycle lane - due to the long construction time - may begin in the 12th year only. In a project like this the boundary conditions are satisfiable, which are:

- the $\mathrm{CO}_{2}$ emission of the community must be reduced by 500 $\mathrm{t} \mathrm{CO}_{2} \mathrm{e}$ in 20 years,

- climate protection education to the residents,

- modernizing and to renovating the heating in 600 households,

- insulating the buildings,

- 10-10 km of bicycle lanes built as a duplicate investment under 20 years,

- an annual maximum of 200 million HUF spent on investments reducing environmental pollution. 


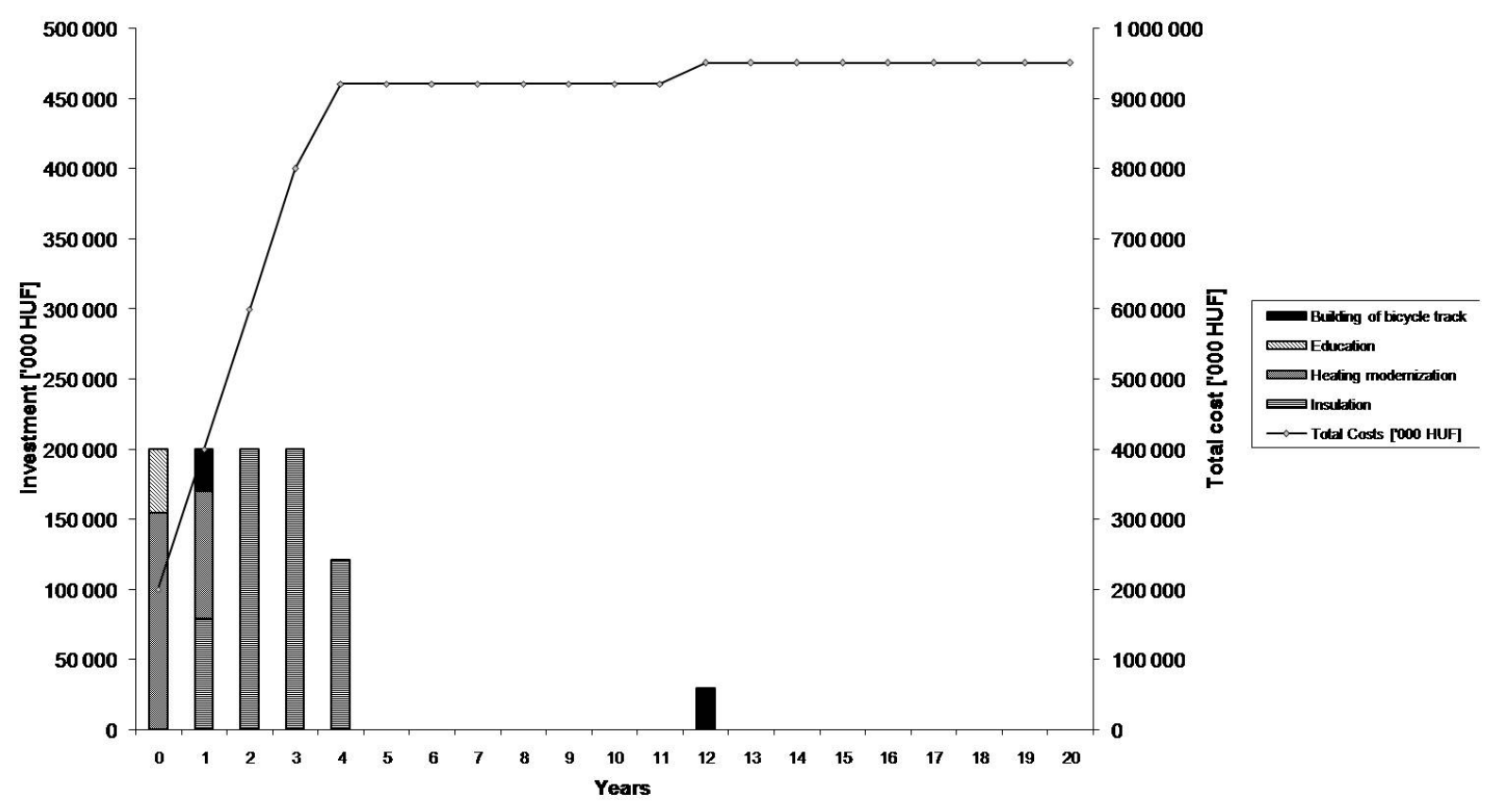

(Source: Own research)

Fig. 2. The budget optimization of environment protection investments

Tab. 2. The sustainability effect matrix of examined investments

\begin{tabular}{|c|c|c|c|}
\hline Type of the investment & Environmental effects & Social effects & Economic effects \\
\hline Heat insulation & $\begin{array}{l}\text { - the decrease of pollution emis- } \\
\text { sions; } \\
\text { - the strengthening of the role } \\
\text { played in atmosphere protection, } \\
\text { adapting to climate change; } \\
\text { - positive effects on the natural en- } \\
\text { vironment }\end{array}$ & $\begin{array}{l}\text { - the creation of new jobs; } \\
\text { - improving local quality of life }\end{array}$ & $\begin{array}{l}\text { - reducing the expenses of settle- } \\
\text { ments, local governments, house- } \\
\text { holds and, agricultural firms; } \\
\text { - the extension of the sources avail- } \\
\text { able with the support of a more cost- } \\
\text { effective operation of local govern- } \\
\text { ments }\end{array}$ \\
\hline Heating modernisation & $\begin{array}{l}\text { - the decrease of pollution emis- } \\
\text { sions; } \\
\text { - the strengthening of the role } \\
\text { played in atmosphere protection, } \\
\text { adapting to climate change; } \\
\text { - positive effect on the natural envi- } \\
\text { ronment; } \\
\text { - positive human health effects } \\
\text { - improvement of the settlements } \\
\text { public health situation with the quan- } \\
\text { titative reduction of stack gases }\end{array}$ & $\begin{array}{l}\text { - the creation of new jobs; } \\
\text { - improving local quality of life }\end{array}$ & $\begin{array}{l}\text { - reducing the expenses of settle- } \\
\text { ments, local governments, house- } \\
\text { holds and, agricultural firms } \\
\text { - stimulating the economy; } \\
\text { - the extension of the sources avail- } \\
\text { able with the support of a more cost- } \\
\text { effective operation of local govern- } \\
\text { ments }\end{array}$ \\
\hline Environmental education & $\begin{array}{l}\text { - short term and long-term complex } \\
\text { environmental effects in all areas }\end{array}$ & $\begin{array}{l}\text { - Promoting the environmental con- } \\
\text { sciousness of future generations; } \\
\text { - contributing to the formation of } \\
\text { climate-conscious communities }\end{array}$ & $\begin{array}{l}\text { - the long term rise of environmen- } \\
\text { tal investments }\end{array}$ \\
\hline The building of bicycle track & $\begin{array}{l}\text { - the decrease of pollution emis- } \\
\text { sions; } \\
\text { - the strengthening of the role } \\
\text { played in atmosphere protection, } \\
\text { adapting to climate change; } \\
\text { - positive effect on the natural envi- } \\
\text { ronment; } \\
\text { - positive human health effects }\end{array}$ & $\begin{array}{l}\text { - contributing to local en- } \\
\text { trepreneurs' living; } \\
\text { - the extension of the opportunities } \\
\text { of job vacancies; } \\
\text { - the improvement of income op- } \\
\text { portunities; } \\
\text { - motivating an environmentally } \\
\text { conscious behaviour }\end{array}$ & $\begin{array}{l}\text { - the decrease of the users ex- } \\
\text { penses with the use of an environ- } \\
\text { mentally conscious traffic behaviour } \\
\text { (e.g. saving fuel costs of cars) } \\
\text { alongside the increase of the local } \\
\text { entrepreneurs' incomes (e.g. bicy- } \\
\text { cle service, rental etc.) }\end{array}$ \\
\hline
\end{tabular}




\section{Results}

Based on the results it can be clearly seen that we have managed to create the optimal investment portfolio according to the pre-determined conditions, and as a result of this the $\mathrm{CO}_{2} \mathrm{e}$ emission has been reduced by $500 \mathrm{t}$ in the settlement populated by 2400 occupants. To achieve this, we defined 950 million HUF as our minimal expense. Taking into consideration the fundamental laws of climate protection and the macro economy, it can be seen that investments occur at the beginning of the examined period.

Table 2 summarizes the effects of the socio-economical and natural-environmental investments appearing in our investigation. The table shows the facts about the direct and indirect benefits generated by these investments among the population, other than the benefits of climate protection. According to the dimensions of sustainability we unfolded the possible effects mapped, focusing on the connections of climate change and sustainability, which, according to the third (2001) and fourth (2007) assessment report of IPCC [5], is on one hand the greatest danger of feasibility of the sustainability of climate change, while on the other hand, the reduction of climate change may benefit from the practical promotion of sustainability, endeavours being aimed at the realisation of exactly this. At the same time, according to Munasinghe (2003) [7] the connection between climate change and sustainable development has a circular character, because climate change has influence on the paths of sustainable development and the different development paths influence the future development of the climate differently.

In order to preserve the quality of life, and the way of living, the correct incentives must be used. For one of the most obvious solutions are the ones which are cost effective, economical, environmentally conscious, and furthermore, they contribute to the standards of living conditions of the local residents (for example improving air quality), and creating job opportunities for the local specialists, which stimulates the local economy. The power optimisation of the communities is an excellent example for this. For the realisation of local sustainability and climate protection efforts it is important to emphasize the fact that in most cases adaptation will have its local benefits that can be realized quickly, or are already connected to other benefits waiting to be solved.

\section{References}

1 2007. évi LX. Törvény az ENSZ Éghajlatváltozási Keretegyezménye és annak Kiotói Jegyzókönyve végrehajtási keretrendszeréról. (Act LX/2007 on the UN Climate Change Treaty and its implementation through the Kyoto Protocol).

2 Csete M, Klímaváltozás és a települések fenntarthatósága., „KLÍMA-21” Füzetek Klímaváltozás - Hatások - Válaszok, Klímavédelmi Kutatási Koordinációs Iroda MTA KSZI. (Climate change and the sustainability of settlements. "KLÍMA-21" Brochures: Climate Change - Impacts - Responses), 2007, pp. 71-88.

3 Energy Information Administration International Energy Annual 2003., available at http://www.eia.doe.gov/
4 Greenhouse gas emission trends and projections in Europe, 2007.

5 IPCC: Intergovernmental Panel on Climate Change, Third (2001) and Fourth (2007) Assessment Report, available at http://www.ipcc.ch/

6 Láng I, Csete M, Jolánkai M, A globális klímaváltozás: hazai hatások és válaszok, A VAHAVA jelentés, Szaktudás Kiadó Ház, Budapest, 2007. (Global climate change: domestic impacts and responses. The VAHAVA report.).

7 Munashinghe M, Climate Change and Sustainable Development Linkages: Points of Departure from the IPCC TAR, 2003.

8 Nemzeti Éghajlatváltozási Stratégia 2008-2025, available at http://www. kvvm.hu/cimg/documents/nes080214.pdf (National Climate Change Strategy 2008-2025).

9 Stern Review: The Economics of Climate Change, 2006, available at http://www.hm-treasury.gov.uk/independent_reviews/stern_ review_economics_climate_change/stern_review_report.cfm

10 Széndioxid-számláló, available at http://wWw.mycarbonfootprint.eu/ $\mathrm{hu} /$ (Carbon footprint calculator).

11 Szlávik J, Környezetgazdaságtan, Typotex Kiadó, Budapest, 2007. (Environmental Economics, Textbook).

12 Takács-Sánta A, A települési klímaprogramok nemzetközi tapasztalatai, 2008. (International experiences of urban climate programs, Manuscript).

13 Tisza-tó Térségi Fejlesztési Tanács honlapja, available at http://wWw. tisza-to-fejlesztes.hu/?d=0

14 Tánczos K, Török Á, The linkage of climate change and energy consumption of Hungary in the road transportation sector, Transport Journal 12/2 (2007), 134-138. 